\title{
Spatial scaling of regional strategic programmes in Finland: A qualitative study of clusters and innovation systems
}

ARTICLE in NORSK GEOGRAFISK TIDSSKRIFT · JUNE 2014

Impact Factor: 0.43 · DOI: 10.1080/00291951.2014.924551

CITATION

1

2 AUTHORS:

Teemu Makkonen

University of Surrey

21 PUBLICATIONS 17 CITATIONS

SEE PROFILE
Tommi Inkinen

University of Helsinki

35 PUBLICATIONS 67 CITATIONS

SEE PROFILE 


\section{Spatial scaling of regional strategic programmes in Finland: A qualitative study of clusters and innovation systems}

\section{TEEMU MAKKONEN \& TOMMI INKINEN}

Teemu Makkonen, Department of Border Region Studies, University of Southern Denmark, Alsion 2, DK-6400 Sønderborg, Denmark. E-mail: teemu@ sam.sdu.dk; Tommi Inkinen, Department of Geosciences and Geography, University of Helsinki, FI-00014 Helsinki, Finland. E-mail: tommi.inkinen@ @elsinki.fi

Innovation systems and clusters are perhaps the most widely used concepts found in recent literature in economic geography focusing on innovative industrial production and locational agglomeration. Both concepts have been universally embraced from the early 1990s onwards. However, recent literature has expressed criticism of their use as tools for policy-making. We studied innovation and cluster rhetoric in a geographical context by using empirical evidence obtained from the policy documents of the Finnish regional councils. We used a theoretical conception of spatial scaling as a geographical framework. Spatial scales proved to be a black box for regional strategies in Finland. Regional strategic programmes use a similar language that ignores the spatial variations of their locations. Clusters and regional innovation systems should be considered as parts of vertical and horizontal interlinkages within the economy and not as individual islands of organizational proximities in isolated contexts. It is argued here that an imprecise understanding of the innovation systems and cluster approaches, both conceptually and practically, has led to some ambiguity, resulting in the use of these terms as buzzwords. This misuse hampers the ability of administrations to execute regional development in their respective areas.

Keywords: cluster, development, innovation policy, scale, spatiality

Running head: Spatial scaling of regional strategic programmes in Finland

This is an Accepted Manuscript of an article published by Taylor \& Francis Group in Norsk Geografisk Tidsskrift-Norwegian Journal of Geography on 26 June 2014, Vol. 68, No. 4, pp. 216-227. Available online: http://www.tandfonline.com/doi/abs/10.1080/00291951.2014.924551 


\section{Introduction}

In accordance with the interpretation of Lawton Smith \& Waters (2011), we consider governance as a key element of regional innovation processes. Consequently, several regionally bounded theoretical concepts and academic research subjects have been introduced to help understand the interrelationships between public organs, private companies and universities, supplemented by intermediating organizations, whose purpose is to support innovation (product, service, or conceptual) in specific locations. Our approach involves two common strands within urban and regional studies and economic geography over the past few decades: clusters (Boschma \& Fornhahl 2011) and innovation systems (Asheim et al. 2011).

Innovation systems are public sector tools and organizational collaborative networks of public and private sector actors, whereas clusters can be considered as geographical concentrations of interconnected firms and public institutions. Both concepts are commonly used in regional development strategies. However, how regions position themselves in relation to other regions (horizontal) and other scales (vertical) varies and the indiscriminate treatment of spatiality in the strategies causes deficiencies in their usability and value to actual development tasks.

Arguably, a well-functioning innovation system should lead to greater regional innovation and to economic growth, whereas cluster dynamics should enhance the productivity and innovativeness of firms within a given cluster. These envisioned prospects caught the attention of policy-makers, and these concepts were integrated into development, innovation, science and regional policies, of which Finland is a textbook example. Early success and encouraging results led to an even more profound and widespread adoption of these approaches as policy implements. The emphasis and promotion of the concepts risked a practice whereby exaggerated statements were made (Canguilhem 1988; Miettinen 2002; Martin \& Sunley 2003; Eskelinen \& Fritsch 2009). Serious doubts about the usefulness of 
these approaches as policy tools may therefore be raised. Thus, after an early and jubilant acceptance of these approaches into policy-making, more critical voices have been raised concerning the lack of clarity of these concepts.

Hadjimichalis \& Hudson (2007) and Bristow (2010) argued against the easy adoption of a one-size-fits-all solution in regional strategy production. This is the empirical topic of our paper. Finland has 18 regional councils (excluding Åland) that function under similar national policy guidelines. However, the population and geo-economic profiles of these regions differ considerably (Table 1). Despite the differences in the underlying compositions of the regions, the policy documentation is often very similar, based on the strategic cloning and uncritical adoption of a competitiveness rhetoric. Thus, although at the national level the Finnish way of simultaneously implementing both clusters and innovation systems has produced good payoffs resulting in its use as a global benchmark, less is known about how these concepts are used in the development work of the regional councils. This is an important avenue of research for other countries to take note of when using the cluster or regional innovation system (RIS) approaches in regional development. The present study provides empirical evidence enabling policy-makers and planning officers at the regional level to understand how they are utilizing the concepts in their development documentation and what kind of benefits and limitations their use contains. Our specific research questions are as follows:

1. How are the concepts of 'innovation systems' and 'clusters' used in Finnish regional policy documents?

2. Is there a conceptual overlap in the usage of 'innovation systems' and 'clusters' in Finnish regional policy documents?

3. How are the scaling mechanisms between international, national and regional contexts understood in Finnish regional policy documents? 
$<$ Table 1. about here>

The three questions lead to a discussion of how regional policy documents could better take into account the theoretical insights of spatial scales of clusters and innovation systems. The article provides an empirical overview of policy guidance documentation on innovation systems and clusters by recognizing the importance of the theoretical approach of spatial scaling. A comparative and integrative view of regional rhetoric is explored. The sources are the main regional development documents used to promote innovation by the Finnish regional councils, corresponding to the NUTS-3 division of the European Union (Nomenclature of Territorial Units for Statistics level 3). Accordingly, we present a synthesizing interpretation of the current language in policy documentation for innovation and development. Thus, we carry out a systematic investigation of the practical use (and misuse) of two key-concepts, taken from the academic literature, in regional strategic programmes in Finland.

\section{Clusters and regional innovation systems}

\section{Conceptual background}

The cluster theory was largely developed and popularized by the seminal works of Porter (1990) and Krugman (1991). Porterian clusters are geographical concentrations of interconnected firms and other institutions (universities, trade associations etc.) in the same or related industry (Porter 2000). Krugman's approach to clusters is based on the accidental emergence of regional clustering and on the importance of external scale economies in sustaining them (Gupta \& Subramanian 2008). However, Krugman (1996) is sceptical of the assumption that regions are expected to compete against each other. In contrast, the concept 
of Porterian clusters supports the idea of regional development planning, as it lies in the notion that 'the enduring competitive advantages in a global economy lie increasingly in local things - knowledge, relationships, motivation - that distant rivals cannot match' (Porter 1998, 78). The competitive advantage of a cluster stems not only from local information flows, inter-firm transactions and communication linkages (usually referred as 'local buzz'), but also from extra-local knowledge sources ('pipeline structure') that connect the cluster to the wider world (Bathelt et al. 2004). The key processes within a cluster are those of cooperation (the vertical dimension of the cluster) and competition (the horizontal dimension of the cluster) (Maskell 2001).

Accordingly, an RIS can be seen as 'the institutional infrastructure supporting innovation within the production structure of a region' (Asheim \& Gertler 2005, 299). The concept of RIS in a study by Cooke (1992) resembles its national counterpart, national innovation systems (NISs), a concept developed by Freeman (1987) and other scholars, including Lundvall (1992), Nelson (1993) and Edquist (1997). However, the common ground behind these approaches led to difficulties and imprecision in defining the boundaries between the scales of innovation systems, and in how to delineate and apply RISs (Laranja 2004). Further, innovation systems can be viewed from either sectoral (Malerba 2002) or technological (Carlsson 1994) perspectives.

The Porterian cluster definition (Porter 2000) comes close to the fundaments of innovation systems (Vuori \& Vuorinen 1994; Miettinen 2002), particularly RISs (Asheim \& Coenen 2006). Notably, regionally concentrated cluster formations laid the foundations for the systemic definitions of innovation processes at the regional level (Braczyk et al. 1998). The ideal type of RIS is a regional cluster of firms that is surrounded by supporting institutional infrastructure (Asheim \& Gertler 2005). Thus, clusters form the basis for RISs. In this evolutionary sense, clusters are part of innovation systems (Doloreux 2002). There is hence 
considerable overlap in the conceptual backgrounds of RISs and clusters. Local and regional innovation economies (and other support systems for regional development) within a nationstate are interlinked and their delineations are problematic (Stræte 2007). However, although the two approaches share common features, it is important to distinguish between them (Asheim et al. 2011). Cluster literature covers geographical concentrations of firms (proximity), performance and competitiveness (competitive advantage), whereas RIS literature emphasizes social capital, networking, institutions, and regional learning processes.

Alternatively, a spatial innovation environment could be considered as 'a system of innovation networks and institutions located within a region, with regular and strong internal interaction that promotes innovativeness and is characterized by embeddedness' (Harmaakorpi 2004, 3). The concept has its roots in the innovation system approach, but also involves the recognition of the microeconomic and policy-related determinants of innovative capability that exist within industrial clusters (Furman et al. 2002). Thus, the concept of regional innovation environment leans on several other theoretical frameworks besides the innovation systems literature and is constructed from a wider array of regional actors as well as other components such as cooperation, networking, local atmosphere, and interactive learning (Harmaakorpi \& Melkas 2005; Tura \& Harmaakorpi 2005).

\section{Practical and policy implications}

According to the literature, well-functioning innovation systems and clusters will generate marked innovative outcomes that result in high regional innovative performance (efficiency) of local actors such as firms. Thus innovation systems and clusters are of particular importance for economic development (Balzat \& Hanusch 2004; Fagerberg \& Srholec 2008; Martínez-Fernández et al. 2012). According to Asheim \& Isaksen (2002), developing interfirm innovation cooperation and strengthening the institutional infrastructure to ensure that a 
higher number of knowledge providers take part in the innovation creation may lead clusters to develop into an RIS. This is in practice the way that the RIS and cluster concepts are embedded in innovation policies; they are used to emphasize the importance of developing innovative capabilities and performance in local firms, as well as improve their business environment including the local institutional infrastructure (Doloreux \& Parto 2005; Kautonen 2012).

The innovation system approach was developed as a framework for studies of economic and innovation performance and as a practical tool for policy-makers (Asheim \& Coenen 2006). In Finland, the NIS approach has been put into effect as a framework for science and technology policies since the early 1990s (Lemola 2002; Boschma \& Sotarauta 2007). Finland was one of the first countries to incorporate the NIS concept into its science and technology policy (Miettinen 2002). The early adoption of innovation system policy paved the way for the introduction of cluster policies in Finland and other Nordic countries. RISs and clusters are systemic approaches and one is relatively easy to adopt after the other has been implemented (Romanainen 2001). The economic recession that Finland underwent in the 1990s led Finnish policy-makers to embrace extensively the cluster-based approach on a national scale. The cluster-based development ideology also had an impact on the regional and local scales (Jääskeläinen 2001; Boschma \& Sotarauta 2007), which led to easy-to-copy adoption of development rhetoric.

Finnish innovation policy was transformed into a more holistic approach by integrating different political sectors in the 2000s (Suorsa 2007). Despite there being no master plan but rather a series of policy measures (Georghiou et al. 2003), this 'policy mix' of innovation systems and cluster approaches worked relatively well in boosting Finland to become one of the most innovative countries in Europe (Sotarauta \& Kautonen 2007). This is why Finnish innovation policy is considered to be a textbook example. However, Miettinen (2002) 
suggested that the Finnish model of innovation policy does not explain the success of the information technology (IT) sector in Finland per se. On the contrary, the strong performance of the IT sector was the principal reason behind the Finnish economic recovery in the 1990s. Hence the effectiveness of the cluster and innovation system approaches in promoting and facilitating the innovativeness of local actors, such as firms, has been questioned (Huber 2012; Uotila et al. 2012).

\section{Spatial scales and regional specificities}

A hitherto little studied aspect of innovation systems and clusters is spatial scales (Coe \& Bunnell 2003; Rees 2005). How policy documentation and guidance consider spatial impacts of innovation activity is especially little known. An example is the question of whether regions recognize that they are parts of nation-states and 'compete' with each other nationally or internationally. Another question is how regional cores are considered, and whether they are independent spatial categories or functional parts of the region. Several other geographically bounded concepts, including local (Muscio 2006) and spatial (Oinas \& Malecki 2002) innovation systems, have been introduced into the innovation system literature to tackle these questions. Ahlqvist \& Inkinen (2007) developed the concept of 'scalar innovation system' in order to problematize the scaling process, i.e. to investigate how innovation activity is reflected in spatially bound realities. Innovation activity emerges and manifests itself differently on a local scale (and related policy documentation) than on a national or an international scale. The regional scale under study here is quite often considered as relatively unimportant; regions seldom have public obligations similar to those of municipal or national jurisdictions (e.g. taxation rights).

Spatial scales may be considered as the starting point for scalar innovation systems. There are also temporal variations in innovation measures. These variations are spatially bound and 
location-specific. We consider these notions to be important for policy guidance documentation and regional authorities. Regional policy-makers and planning officers should recognize the interaction and spatial scaling process that innovation activities have in location-bound contexts. Locations, such as cities, are interlinked network nodes in which spatial interactions takes place in various forms (Graham 1998). Innovative units (e.g. companies or universities) may also directly interact with international or global markets. Therefore, the role and significance of clusters and RISs should be considered in the light of the challenges that the regions in question pursue.

In empirical settings the theoretical conception of scaling can be recognized in the way that the studied regions identify and view themselves as parts of broader national and international scales and also how they localize themselves as innovation-creating locations. The recognition of the local context (as the starting point for innovation) and an understanding of the utilization of comparative advantages in competition and collaboration with other national and international regions are elemental for well-functioning development strategies, i.e. scaling refers to issues that may incorporate a region within the context of Finland (as a nation responsible for NIS) and also the European Union (international) and global scales. Local variations in the intensity of interaction between these wider spatial scales (national and international) especially create regional differentiation in innovation processes (Doloreux 2002; Doloreux \& Parto 2005; Jauhiainen \& Moilanen 2012).

The scaling effect is a characteristic of RISs, as interactions between institutions are more relevant at the regional than the national scale, in which the central elements are the flows of knowledge, resources and human capital (Autio 1998). RIS neither exists nor develops in isolation; inter-regional, national and global links as well as multinational enterprises influence single innovation systems (Criscuolo et al. 2005). This notion raises a complex question (Carlsson et al. 2002): how to delineate the system and identify the actors and key 
relationships so that the important interactions take place within rather than outside the system? This question incorporates the essence of spatial scaling, i.e. the vertical connections of economic impacts that innovation produces and the horizontal recognition of local strengths and weaknesses (Balzat \& Hanusch 2004).

The framework of our study is presented in Fig. 1. This indicates the similarities and differences between the study concepts (clusters and RIS) in policy documentation and shows their association with spatial scaling. The background of our analytical model is formed from a conceptual investigation on the varying components and processes that are seen to constitute as well as direct the development and success of RISs and clusters in individual regions. This also includes the way the concepts are defined and applied as tools and goals for development in the analysed documents. Accordingly, an important issue here is whether or not the limitations of the concepts have been acknowledged or discussed amongst the development rhetoric. The horizontal and vertical interaction of regions was investigated with respect to 1) the significance and meaning given to other Finnish regions and 2) wider (national and international) spatial scales, and 3) in terms of the importance laid on localities, in the strategic development documents, within the regions.

<Fig. 1. about here>

In practice, the approaches have nuances according to regional specificities. Cooke (2004; see also Asheim \& Isaksen 2002 for a reference typology) has divided RISs in terms of governance into 1) locally organized grassroots RIS, 2) vertically collaborative network RIS and 3) dirigiste RIS led from outside the region. Accordingly, the Finnish regional system is characterized by a strong concentration of innovation activities in the largest city cores. Therefore, the question how to induce innovation activities in areas outside the Finnish 
capital region of Helsinki and other larger cities has constituted one key-topic in the contemporary Finnish innovation policy debate (Inkinen 2005). The development of the regions and promotion of innovation activities in Finland are mainly implemented through the government's special programmes, designed to meet regional needs (Jauhiainen 2008). Finnish regions can influence these national programmes indirectly through local initiatives, but these initiatives have no decisive role when innovation and science policies are being formulated (Sotarauta \& Kautonen 2007; Sotarauta 2010). Thus, most Finnish regions can be seen as having many characteristics of dirigiste RISs. The possibility of RIS development for every individual region has been questioned due to obstacles faced by the less-favoured regions (Tödtling \& Trippl 2005; Zabala-Iturriagagoitia et al. 2008). In addition, a political debate has arisen about the future role of the regional councils regarding regional and innovation policy implementation: it seems that the contemporary municipal reforms in Finland may devolve some of the authority for regional development from the regional councils to the large city cores. This type of future development, concerning the role of the regional councils, would provide further work for scholars and policy-makers in the assessment of regional development support systems in Finland and potentially provide a feasible starting point for comparative analysis among Nordic countries.

\section{Empirical setting: Finland's regional councils}

Finland's regional councils are statutory authorities that operate as regional development and planning organs. There are 18 Regional Councils in mainland Finland (Fig. 2). Although the regional councils do not have significant regulatory powers, they exert some power through their central position in the organization of regional planning and play an important role in the regional policy of the European Union (Haveri \& Airaksinen 2007). As an exception, the Regional Council of Kainuu acted as a self-governing region from 2005 to 2012 as the Joint 
Authority of Kainuu Region. Regional councils, including the Joint Authority of Kainuu Region, act to promote the development and well-being of the respective regions according to the needs of the region as a whole. The work of the regional councils emphasizes both longterm planning (visions) and the near future (programmes).

<Fig. 2. about here>

Two central documents in this development administration work are the regional plan (maakuntasuunnitelma) and regional strategic programme (maakuntaohjelma). The regional plan lays out the long-term vision and developmental objectives for the region and the strategy for achieving these objectives. The regional strategic programme is a medium-term implement (Fig. 3) that is formulated according to the objectives presented in the regional plan. The strategic programme details how the strategy (regional development targets, key projects, and measures and a financing plan) will be implemented in the near future. Furthermore, an implementation plan (toteuttamissuunnitelma) for the regional strategic programme is prepared every year, presenting the most essential projects to be executed to fulfil the regional strategy. Implementation of the plan is a collaboration between the regional councils, the state, municipalities, regional Centres for Economic Development, Transport and the Environment, regional state administrative agencies, and other regional actors such as institutes for higher education. A separate regional land-use plan (maakuntakaava) provides guidelines for municipalities. The regional councils also administer other locally implemented programmes, including the European Union's Regional Development Fund and Social Fund.

<Fig. 3. about here> 


\section{Data and methods}

\section{Textual content analysis}

We used content analysis to document our textual data. The method is widely used due to its flexibility in combining quantitative and qualitative frameworks, ensuring rigour and objectivity in analysing documents (Weber 1990; Neuendorf 2002; White \& Marsh 2006). Our textual content analysis follows this methodological rigidity by using a set of keywords in an automated content search according to which the data are first classified and then interpreted. In addition to word combination and searches, we have read all relevant documents in order to gain a general interpretative understanding of the specifications regarding each document. This methodological rigidity allows others to repeat the analysis done here, which was a major reason for selecting this tool.

\section{Data}

This study is based on the contemporaneous regional strategic programmes of the 18 Finnish regional councils (Appendix 1). In content analysis a text is analysed in terms of categories and themes, which are based on existing theories and previous research. In this study, the main themes were clusters and RISs. Following Asheim et al. (2011), these were analysed in accordance with the categories of the subdivision of the conceptual background shown in Fig. 1, as follows: what constitutes an RIS or cluster (components); what kind of processes exist between the actors (processes); how an RIS or cluster is defined (definitions); whether there are limitations in using these concepts (limitations); and how they are used in development policies (development tools and goals). This conceptual background provides a tool for the policy document analysis. 
We used word searches with phrases related to innovation systems, environments and structures (innovaatiojärjestelmä; innovaatioympäristö; innovaatiorakenteet) in addition to clusters (klusteri). First we used these key phrases to flag the paragraphs in the documents that covered innovation systems and clusters, or concepts clearly related to them. Then we categorized these paragraphs according to the subdivision. In some cases the paragraphs included discussion related to several subdivisions of the same theme. In these cases, the selection was made on the basis of the emphasis given to the relevant subdivisions in the paragraph. Similarly, some paragraphs contained both cluster-related and RIS-related discussions, in which case they were included in both categories and analysed separately under both headings. In the third stage, we analysed the paragraphs in terms of the conceptual framework presented in Fig. 1 to allow an estimation of the feasibility of the clusters and RISs in the regional strategic programmes. Accordingly, the contents of these paragraphs are first briefly introduced as a comparative overview (research question 1), followed by a more analytical discussion of the shortcomings of the RIS and cluster approaches taken in the regional strategic documents (research question 2). Lastly, the way that horizontal linkages and vertical scaling, depicted in Fig. 1, are discussed and understood by the regional councils is examined (research question 3).

\section{Limitations and critique}

The main limitation of the chosen methodology is the bias that may be generated by documentation reading. The documents were read by one researcher (first author) and verified by another (second author). This helped to achieve an intersubjective consideration of the functionality of the applied analytical framework together with an estimation of the robustness of the classification's functionality. Bias can also be lessened by using a quantitative word count process that allows for replication. Thus the findings do not solely 
rely on the trustworthiness of the author conducting the analysis (White \& Marsh 2006). A common limitation of qualitative research is superficiality when results are not interpreted properly (Weber 1990; Neuendorf 2002; Tuomi \& Sarajärvi 2002). Bearing these limitations in mind, the empirical analysis of the policy documents revealed certain key issues that have been identified previously in theoretical literature on RISs and clusters. The identified lines of argument (discourses) illustrate the ambitions of regional councils in the execution of planning on a regional scale in Finland.

The data in our study transcend the case study context as they were obtained from numerous data sources (regional councils). We consider our analysis robust due to the following properties that are relevant to documentation data of case studies (Yin 1994): the data may be reviewed (read and interpreted) repeatedly, treated as quantitative raw data (calculus of frequencies), and considered robust over time (several existing sources). Furthermore, the data are easily available on the internet as e-documents or from libraries as hardcopy versions.

\section{Results}

We found that the local knowledge base and know-how was taken into account and utilized by including representatives of local universities, research institutes and other knowledge organizations in the preparation of the regional strategic programmes. However, the evident similarities of the programmes across Finland were found to have rendered this cooperation somewhat unproductive (Bristow 2010). The regional socio-economic and industrial base specifics were indeed introduced, but the subsequent promotional targets and proposed activities remained general. 
The usage of innovation systems and clusters in Finnish regional policy documents In terms of absolute number of paragraphs, the use of the cluster concept was more commonplace than the use of the RIS approach. This was still the case after broadening the spectrum of innovation systems by analysing paragraphs that referred to innovation environments and structures. For example, in the regional strategic programmes of Ostrobothnia and Lapland, clusters were mentioned in more than 40 and 30 paragraphs respectively. Regional councils utilized both approaches alongside each other in their regional strategic programmes. The sole exception was the region of Central Finland, for which there was no mention of 'innovation systems'. Both concepts have been used in the regional strategic programmes to describe the components and processes of the regions, but even more so as tools for reaching the development goals in the respective regions.

Definitions and limitations related to the concepts were largely ignored in the data. Table 2 summarizes the features of RISs and clusters identified in the policy documents.

$<$ Table 2. about here>

In the programmes the core of the innovation system was perceived to be constructed from local firms via the networking and cooperative activities between them and the universities. Other institutes of higher learning and research in addition to intermediaries were also emphasized in the paragraphs. The importance of technology transfer was hence highlighted. All in all, the significance of the notion that innovation processes happen in cooperation and interaction between different actors was present in the documents. An effective RIS in the strategic documents was regarded as a present or future success factor, which added to the local attractiveness, and as an enabler of a region's growth. On the other hand, clusters were frequently used to define a distinct industry coalition (such as maritime, tourism, or forest) in 
relation to others, and also to stress the importance of that industry as a regional strength, cooperating with local government and other institutions. Other widely applied uses of the term 'cluster' in the regional strategic programmes were found for the attempted development of a completely new cluster in the region. This was done by stressing the importance of networking between cluster interfaces in order to promote regional development and enhance employment opportunities.

Although local know-how was seen to be extremely important in the discussion related to both concepts, it still appeared that the development tools to reach 'common' goals (regional competitiveness) varied. The development of the RIS through university-industry partnerships was seen as the key to regional innovation performances, and further to economic growth. In contrast, the main emphasis for clusters was on operational preconditions within clusters and between cluster interfaces. However, a clear understanding of how cluster or RIS development should be implemented to achieve the desired aims seemed to be lacking in the documents.

Because the regional strategic programmes are essentially used as guidance rather than as binding objectives, the discourse of RISs and clusters in them were in general positive; a principal objective was to develop a strong 'common spirit' to promote the development goals of the regions. Nonetheless, a critical consideration of cluster and RIS development prospects for the most peripheral of Finnish regions, with limitations in their population characteristics (Table 1), was largely missing. However, in Häme the views concerning clusters as a resource and development tool were more 'realistic', as it was openly acknowledged that there was not a strong enough sector to be labelled a proper regional cluster. It was also admitted that the interaction between organizations that should constitute an RIS in Lapland was not sufficiently developed. Even so a predominant finding was that clusters and RISs were hailed with a fair amount of development optimism, but the terms 
were generally used without any particularly clear and significant meaning, that is, they were used as buzzwords.

The conceptual overlap in the usage of innovation systems and clusters in Finnish regional policy documents

We kept in mind various cluster and RIS definitions but in particular refer to the cluster definition by Porter (2000) and the RIS definition by Asheim and Gertler (2005) due to their informative and condense structure. In one of the few strategic documents where the above definitions were indicated, the idea of a cluster was expressed as: 'a know-how agglomeration comprised of functionally interlinked enterprises, universities and other institutes of higher education, research institutes and the government' [authors' translation] (Pohjois-Karjalan Maakuntaliitto 2010, 73). In contrast, RISs were regarded as being constructed from: 'the interaction between institutes of higher education, research institutes, intermediaries and firms' [authors' translation] (Keski-Pohjanmaan Liitto 2010, 17). Thus, the first signs of ambiguity can be seen to have arisen in the definitions of the concepts, as both approaches are comprised of very similar components and processes.

Confusion was also found in the case of the innovation environments. The term 'innovation structure' was used in some of the regional strategic programmes. Both terms were frequently used alongside RISs when discussing issues clearly related to the RIS approach. In the documents, the theoretical definition of an innovation environment (Harmaakorpi 2004) bore resemblance to the definition of an RIS (Asheim \& Gertler 2005). In this respect, innovation systems were defined as 'a well-functioning network of innovation environments' [authors' translation] (Pohjois-Pohjanmaan Liitto 2010, 43). However, in the regional strategic programmes innovation environments were often used in a sectoral sense, 
i.e. to describe the innovation-related activity within a single industry as in Furman et al. (2002).

The strategic documents' strong emphasis on developing the local industrial sectors also arose in paragraphs that covered the topic of branch-specific innovation systems within the regions as types of sectoral RISs. Therefore, in relation to the goals of the RISs stated in the regional strategic programmes, we noted that the language used was quite similar to that used for cluster development, i.e. of regional competiveness and comparative advantage. Thus it seems that in this case the critique of the 'fuzzy boundaries' of the approaches is well justified. The imprecision between the theoretical delineation of RIS and cluster boundaries was mirrored in the regional strategic programmes. A summary of the features and main shortcomings are presented as a synthesis in Table 3.

$<$ Table 3. about here>

The ways in which clusters and RISs have been understood and implemented in the regional strategic programmes are by and large very similar. On most occasions it seemed that this led to some ambiguity with respect to what was actually meant by the terms used. Hence the use of these approaches as a policy option was found to be imprecise and non-specific. This hampers the chances of such actions having a positive impact on regional development.

The scaling mechanisms for international, national and regional contexts in Finnish regional policy documents

The perceived importance of (vertical) global links (Fig. 1), international and national administrations were found to be prominent for both themes. However, the potential importance of the European Union was only manifested though the use of structural funds 
allocated to the regions. The global scale was considered as a threat for old industries (demand shocks and loss of workplaces), as a challenge for new industries (increasing global competition), and as opportunities for emerging industries (the possibility of entering first into global markets). The reasoning of how to tap into global knowledge resources was not explicitly written out in the strategic documents. The global scale was pictured, in a traditional way, either as the location of competitors or as a source of customers. These results indicate that regional strategies rely extensively on well-known slogans that have been used in regional development rhetoric for decades. Visionary views of the potentials of the emerging signals of location-based (competitive) advantages are absent from our data.

The vertical scaling (depicted in Fig. 1) towards the national level of Finland is mostly discussed through national cluster programmes and through diverse funding mechanisms. Most of the regional strategic programmes claim that there are elements (parts of a cluster network) of different national clusters (such as an information and communications technology cluster, a maritime cluster, or forestry cluster) within the region. However, there is no explanation of how these linkages function in practice or how the region positions itself within the cluster in relation to other regions included in the same cluster (the horizontal axis in Fig. 1). This deficiency indicates a clear problem of cluster definition in regional strategies. The regional councils use the term 'cluster' to refer to networks of spatially distributed industries in the same field; for example, a 'forest cluster' is not a location-bound concentration but a network of local agglomerations of that specified industry. The national level was considered as an enabler of the clusters within Finland as a nation-state. The potential assets were understood to be derived from the guidance and funding of the national state, which deemed the situation to be more favourable for some regions (e.g. funding mechanisms and location of universities and public research institutes) than others. 
Discussion of the importance of horizontal linkages (depicted in Fig. 1) between RISs and clusters were absent in the documentation. The need for developing these linkages between the regions was recognized, but on the regions' own terms, which might ignore the opportunities of mutually constructed competitive advantages or the advantages of interregional cooperation. Thus, the relationship between regions was seen as a state of competition, where regions were competing against each other for the same pool of knowledge and resources including educated workers, high-tech firms and innovation-related national funding. The development strategies of the regions emphasized cooperation on an intra-regional scale. The limitations of this approach were better understood the more geographically remote the region was when viewed from the economic and administrative centre of Helsinki. For example, in Kainuu and Lapland, striving towards establishing common networks regardless of regional boundaries was a more prominent aim compared to the regions in the south of Finland.

Regional strategies mostly considered the vertical scaling (Fig. 1) towards smaller regional units (municipalities, localities or firms) as a network of subcontractors that strengthen the regions' competitiveness and innovativeness. This echoed the difficulties in realizing the geographical scales of a cluster in Finland, in terms of national versus sub-regional smallscale 'mini-clusters' or 'sub-clusters' referred to in the strategic documents. Similarly, the ambiguity related to the boundaries of scalar innovation systems was evident in the regional strategic programmes as there was some discussion of regional and smaller local innovation systems within larger regional systems. How the boundaries between the scales are delineated remains unclear. The transitions from local to regional innovation systems were accomplished without academic knowledge regarding these concepts and without discussing the problems related to scaling. 


\section{Discussion and conclusions}

We studied RISs and clusters, which by definition share many common features, as policy concepts. They have been widely popular among policy-makers, as the main idea behind these approaches is appealing. The study verified that the RIS approach and the cluster models have been and still are used in contemporary regional strategies. The application of decades-old work raises questions about their ability to function as innovative visions for the future. The analysis also indicated that policy documents treat clusters and innovation systems mainly as isolated islands that ignore spatial scaling and complexity. Different types of development actions require different types of support systems (e.g. intermediaries). Moreover, different innovation-creating companies and individuals act differently: policies should thus begin from an understanding and recognition of the local scale as a site of the actualization of the innovation.

First, drawing from these results, we argue that, although RISs and clusters serve as an important approach for innovation and economic studies, the ambiguity inherent in the studied definitions of the concepts leads to unclear uses of these approaches in regional strategy documents. According to the content analysis, the problems related to the theoretical underpinnings and definitions behind the concepts (Stræte 2007) have been transferred quite straightforwardly to the regional strategic programmes. It has appeared to be difficult for regional council officials to grasp what an RIS or cluster actually is or should be.

Second, Finnish innovation and science policy is largely nationally led (Sotarauta \& Kautonen 2007), that is, most Finnish regions can be seen as having many characteristics of dirigiste RISs (Cooke 2004; Jauhiainen \& Moilanen 2012), and this has added to the confusion about applied terminology in addition to the confusion in recognizing the spatial economic impacts that are expected to be derived from innovations (an important point for other counties following similar type of national and regional distribution of work in regional 
development planning). In Finland this has resulted in the use of 'clusters' and 'innovation systems' as buzzwords. Hence they are not understood as contextualized location specific agglomerations of economic activity with horizontal and vertical dimensions to other locations (Asheim \& Isaksen 2002; Cooke 2004). This absence generally causes regional innovation strategies to have poor foundations for spatially aware strategy-building in decision-making. Hence the utility of the concept of RIS in the development of peripheral and rural regions in Finland and other countries can be questioned (Asheim \& Isaksen 2002; Tödtling \& Trippl 2005; Zabala-Iturriagagoitia et al. 2008). This challenges the academic community engaged in theorizing RISs and cluster to define more precisely the following: first, what the building blocks comprising an innovation system or a cluster are; second, what the enabling processes between these components are; and third, how innovation systems and clusters should be delineated from a geographical or sectoral point of view (Carlsson et al. 2002). Otherwise, there is a real risk of missing the potential benefits these concepts could offer for regional development. Moreover, local policy-makers and planning officers should pay closer attention to the theoretical and conceptual underpinnings of RISs and clusters to avoid mere cloning of regional development strategies from each other and to avoid the buzzword type use of the concepts (Bristow 2010).

In sum, regional strategic programmes apply similar language that often ignores spatial context. The horizontal and vertical understanding and recognition of interlinkages between local, regional, national or international is rare and simplified in current regional strategies. Too often regional documents tend to ignore the spatial structures that have substantial effects upon the actualization of innovation activity. Spatial scales and geographical concepts of vertical and horizontal connectivity provide one feasible and little studied starting point for the quest to identify spatial impacts of innovations locally, regionally, nationally, and internationally. 
The use of innovation literature might help to overcome the absence problems of spatial recognition and scaling. First, the use of more explicitly described development tools such as the regional development platform method (Harmaakorpi 2006) or intentional innovation communities (Thomas et al. 2011) could produce more applicable and focused narratives for regional strategies with visionary tools and goals as a replacement for 'recycling' bits and pieces from the decades-old competitiveness debate. Second, regions should abandon the view of other regions as competitors. Instead, collaboration with others at the horizontal scale would enhance the possibilities of economic development in accordance with the strengths of the individual regions in question. Third, the vertical scale should not be viewed only as a threat. Rather, the vertical linkages from local to the world economy should be more extensively explored and included in the regional strategies. The world is globalizing in many ways, and Finnish regions should not and cannot ignore this, but instead should engage themselves in finding ways to benefit from it.

\section{Acknowledgements}

We would like to thank the editor of the journal and three anonymous reviewers for their comments on improving the paper. Accordingly, we are indebted to Mr. Arttu Paarlahti for his help with the figures. A much earlier version of this paper was presented at the 15 th Uddevalla Symposium held in Faro, Portugal in June 2012.

\section{References}

Ahlqvist, T. \& Inkinen, T. 2007. Technology foresight in scalar innovation systems: A spatiotemporal process perspective. Fennia 185:1, 3-14. 
Asheim, B. \& Coenen, L. 2006. Contextualising regional innovation systems in a globalising learning economy: On knowledge bases and institutional frameworks. Journal of Technology Transfer $31: 1,163-173$.

Asheim, B. \& Gertler, M. 2005. The geography of innovation: Regional innovation systems. Fagerberg, J., Mowery, D. \& Nelson, R. (eds.) The Oxford Handbook of Innovation, 291-317. Oxford University Press, Oxford.

Asheim, B. \& Isaksen, A. 2002. Regional innovation systems: The integration of local 'sticky' and global ‘ubiquitous' knowledge. Journal of Technology Transfer 27:1, 77-86.

Asheim, B., Lawton Smith, H. \& Oughton, C. 2011. Regional innovation systems: Theory, empirics and policy. Regional Studies 45:7, 875-891.

Autio, E. 1998. Evaluation of RTD in regional systems of innovation. European Planning Studies 6:2, $131-140$.

Balzat, M. \& Hanusch, H. 2004. Recent trends in the research on national innovation systems. Journal of Evolutionary Economics 14:2, 197-210.

Bathelt, H., Malmberg, A. \& Maskell, P. 2004. Clusters and knowledge: Local buzz, global pipelines and the process of knowledge creation. Progress in Human Geography 28:1, 31-56.

Boschma, R. \& Fornhahl, D. 2011. Cluster evolution and a roadmap for future research. Regional Studies 45:10, 1295-1298.

Boschma, R. \& Sotarauta, M. 2007. Economic policy from an evolutionary perspective: The case of Finland. International Journal of Entrepreneurship and Innovation Management 7:2-5, 156-173.

Braczyk, H.J., Cooke, P. \& Heidenreich, M. (eds.) 1998. Regional Innovation Systems: The Role of Governances in a Globalized World. UCL Press, London.

Bristow, G. 2010. Critical Reflections on Regional Competitiveness: Theory, Policy, Practice. Routledge, London.

Canguilhem, G. 1988. Ideology and Rationality in the History of Science. MIT Press, Cambridge.

Carlsson, B. 1994. Technological systems and economic growth: Comparing Finland, Sweden, Japan and the United States. Vuori, S. \& Vuorinen, P. (eds.) Explaining Technical Change in a Small Country: The Finnish National Innovation System, 159-183. Physica-Verlag, Heidelberg. 
Carlsson, B., Jacobsson, S., Holmén, M. \& Rickne, A. 2002. Innovation systems: Analytical and methodological issues. Research Policy 31:2, 233-245.

Coe, N. \& Bunnell, T. 2003. 'Spatializing' knowledge communities: Towards a conceptualization of transnational innovation networks. Global Networks 3:4, 437-456.

Cooke, P. 1992. Regional innovation systems: Competitive regulation in the new Europe. Geoforum $23: 3,365-382$.

Cooke, P. 2004. Introduction: Regional innovation systems - An evolutionary approach. Cooke, P., Heidenreich, M. and Braczyk, H.-J. (eds.) Regional Innovation Systems: The Role of Governances in a Globalized World, 1-18. Routledge, London.

Criscuolo, P., Narula, R. \& Verspagen, B. 2005. Role of home and host country innovation systems in R\&D internationalisation: A patent citation analysis. Economics of Innovation and New Technology 14:5, 417-433.

Doloreux, D. 2002. What we should know about regional systems of innovation. Technology in Society 24:3, 243-263.

Doloreux, D. \& Parto, S. 2005. Regional innovation systems: Current discourse and unresolved issues. Technology in Society 27:2, 133-153.

Edquist, C. (ed.) 1997. Systems of Innovation: Technologies, Institutions and Organizations. Pinter, London.

Eskelinen, H. \& Fritsch, M. 2009. Polycentricity in the North-eastern periphery of the EU territory. European Planning Studies 17:4, 605-619.

Fagerberg, J. \& Shrolec, M. 2008. National innovation systems, capabilities and economic development. Research Policy 37:9, 1417-1435.

Freeman, C. 1987. Technology Policy and Economic Performance: Lessons from Japan. Pinter: London.

Furman, J., Porter, M. \& Stern, S. 2002. The determinants of national innovative capacity. Research Policy 31:6, 899-933.

Georghiou, L., Smith, K., Toivanen, O. \& Ylä-Anttila, P. 2003. Evaluation of the Finnish Innovation Support System. Ministry of Trade and Industry, Helsinki. 
Graham, S. 1998. The end of geography or the explosion of the place? Conceptualizing space, place and information technology. Progress in Human Geography 22:2, 165-185.

Gupta, V. \& Subramanian, R. 2008. Seven perspectives on regional clusters and the case of Grand Rapids office furniture city. International Business Review 17:4, 371-384.

Hadjimichalis, C. \& Hudson, R. 2007. Rethinking local and regional development: Implications for radical political practice in Europe. European Urban and Regional Studies 14:2, 99-113.

Harmaakorpi, V. 2004. Building a Competitive Regional Innovation Environment: The Regional Development Platform as a Tool for Regional Innovation Policy. DSc (Tech.) Thesis, Helsinki University of Technology, Finland.

Harmaakorpi, V. 2006. Regional Development Platform Method (RDPM) as a tool for regional innovation policy. European Planning Studies 14:8, 1085-1104.

Harmaakorpi, V. \& Melkas, H. 2005. Knowledge management in regional innovation networks: The case of Lahti, Finland. European Planning Studies 13:5, 641-659.

Haveri, K. \& Airaksinen, J. 2007. Inter-municipal cooperation in Finland: Old traditions and new promises. Hulst, R. \& van Montfort, A. (eds.) Inter-municipal Cooperation in Europe, 39-65. Springer, Dordrecht.

Huber, F. 2012. Do clusters really matter for innovation practices in information technology? Questioning the significance of technological knowledge spillovers. Journal of Economic Geography 12:1, 107-126.

Inkinen, T. 2005. European coherence and regional policy: A Finnish perspective on the observed and reported territorial impacts of EU research and development policies. European Planning Studies $13: 7,1113-1121$.

Jääskeläinen, J. 2001. Klusteri - tieteen ja politiikan välissä: Teollisuuspolitiikasta yhteiskuntapolitiikkaan. ETLA, Helsinki.

Jauhiainen, J. 2008. Regional and innovation policies in Finland - Towards convergence and/or mismatch. Regional Studies 42:7, 1031-1045. 
Jauhiainen, J. \& Moilanen, H. 2012. Regional innovation systems, high-technology development, and governance in the periphery: The case of Northern Finland. Norsk Geografisk TidsskriftNorwegian Journal of Geography 66:3, 119-132.

Kautonen, M. 2012. Balancing competitiveness and cohesion in regional innovation policy: The case of Finland. European Planning Studies 20:12, 1925-1943.

Keski-Pohjanmaan Liitto 2010. Elinvoimainen kestävän kasvun maakunta: Keski-Pohjanmaan maakuntasuunnitelma 2030 ja maakuntaohjelma 2011-2014. Keski-Pohjanmaan Liitto, Kokkola.

Krugman, P. 1991. Geography and Trade. MIT Press, Cambridge.

Krugman, P. 1996. Making sense of the competitiveness debate. Oxford Review of Economic Policy $12: 3,17-25$.

Laranja, M. 2004. Innovation systems as regional policy frameworks: The case of Lisbon and Tagus Valley. Science and Public Policy 31:4, 313-327.

Lawton Smith, H. \& Waters, R. 2011. Scientific labour markets, networks and regional innovation systems. Regional Studies 45:7, 961-976.

Lemola, T. 2002. Convergence of national science and technology policies: The case of Finland. Research Policy 40:8-9, 1481-1490.

Lundvall, B.Å. (ed.) 1992. National Systems of Innovation: Towards a Theory of Innovation and Interactive Learning. Pinter, London.

Malerba, F. 2002. Sectoral systems of innovation and production. Research Policy 31:2, 247-264.

Martin, R. \& Sunley, P. 2003. Deconstructing clusters: Chaotic concept or policy panacea. Journal of Economic Geography 3:1, 5-35.

Martínez-Fernández, M.T., Capó-Vicedo, J. \& Vallet-Bellmunt, T. 2012. The present state of research into industrial clusters and districts: Content analysis of material published in 1997-2006. European Planning Studies 20:2, 281-304.

Maskell, P. 2001. Towards a knowledge-based theory of the geographical cluster. Industrial and Corporate Change 10:4, 921-943.

Miettinen, R. 2002. National Innovation System: Scientific Concept or Political Rhetoric. Edita Publishing, Helsinki. 
Muscio, A. 2006. From regional innovation systems to local innovation systems: Evidence from Italian industrial districts. European Planning Studies 14:6, 773-789.

Nelson, R. (ed.) 1993. National Innovation Systems. Oxford University Press, Oxford.

Neuendorf, K. 2002. The Content Analysis Guidebook. Sage Publications, Thousand Oaks.

Oinas, P. \& Malecki, E. 2002. The evolution of technologies in time and space: From national and regional to spatial innovation systems. International Regional Science Review 25:1, 102-131.

Pohjois-Karjalan Maakuntaliitto 2010. Pokat 2014: Pohjois-Karjalan maakuntaohjelma 2011-2014. Pohjois-Karjalan Maakuntaliitto, Joensuu.

Pohjois-Pohjanmaan Liitto 2010. Pohjois-Pohjanmaa - nuorten maakunta: Maakuntasuunnitelma 2030 ja maakuntaohjelma 2011-2014. Pohjois-Pohjanmaan Liitto, Oulu.

Porter, M. 1990. The Competitive Advantage of Nations. The MacMillan Press, London.

Porter, M. 1998. Clusters and the new economics of competition. Harvard Business Review 1998:November-December, 77-90.

Porter, M. 2000. Location, competition, and economic development: Local clusters in a global economy. Economic Development Quarterly 14:1,15-34.

Rees, K. 2005. Interregional collaboration and innovation in Vancouver's emerging high-tech cluster. Tijdschrift voor Economische en Sociale Geografie 96:3, 298-312.

Romanainen, J. 2001. The cluster approach in Finnish technology policy. den Hertog, P., Remoe, S., Bergman, E. \& Charles, D. (eds.) Innovative Clusters: Drivers of National Innovation Systems, 377-388. OECD, Paris.

Sotarauta, M. 2010. Regional development and regional networks: The role of regional development officers in Finland. European Urban and Regional Studies 17:4, 387-400.

Sotarauta, M. \& Kautonen, M. 2007. Co-evolution of the Finnish national and local innovation and science arenas: Towards a dynamic understanding of multi-level governance. Regional Studies $41: 8,1085-1098$.

Statistics Finland 2012a. Educational Structure of Population. (http://pxweb2.stat.fi/database/StatFin/kou/vkour/vkour_en.asp) (accessed March 2012). 
Statistics Finland 2012b. Employment.

(http://pxweb2.stat.fi/database/StatFin/vrm/tyokay/tyokay_en.asp) (accessed March 2012).

Statistics Finland 2012c. Population Structure.

(http://pxweb2.stat.fi/database/StatFin/vrm/vaerak/vaerak_en.asp) (accessed March 2012).

Stræte, E.P. 2007. A system perspective on innovation in the Norwegian dairy industry. Norsk Geografisk Tidsskrift - Norwegian Journal of Geography 61:1, 25-33.

Suorsa, K. 2007. Regionality, innovation policy and peripheral regions in Finland, Sweden and Norway. Fennia 185:1, 15-29.

Thomas, P., Adapa, S., Davies, E., Fortunato, M. \& Alter, T. 2011. Intentional innovation communities: Strengthening innovation performance in the northern inland region of NSW. Extension Farming Systems Journal 7:2, 126-128.

Tödtling, F. \& Trippl, M. 2005. One size fits all: Towards a differentiated regional innovation policy approach. Research Policy 34:8, 1203-1219.

Tuomi, J. \& Sarajärvi, A. 2002. Laadullinen tutkimus ja sisällönanalyysi. Tammi, Helsinki.

Tura, T. \& Harmaakorpi, V. 2005. Social capital in building regional innovative capability. Regional Studies 39:8, 1111-1125.

Uotila, T., Harmaakorpi, V. \& Hermans, R. (2012). Finnish mosaic of regional innovation system: Assessment of thematic regional innovation platforms based on related variety. European Planning Studies 20:10, 1583-1602

Vuori, S. \& Vuorinen, P. 1994. The rigidities and potential of a national innovation system. Vuori, S. \& Vuorinen, P. (eds.) Explaining Technical Change in a Small Country: The Finnish National Innovation System, 206-215. Physica-Verlag, Heidelberg.

Weber, R.P. 1990. Basic Content Analysis. Sage Publications, Newbury Park.

White, M.D. \& Marsh, E. 2006. Content analysis: A flexible methodology. Library Trends 55:1, $22-$ 45.

Yin, R.K. 1994. Case Study Research: Design and Methods. Sage Publications, Thousand Oaks.

Zabala-Iturriagagoitia, J., Gutiérrez-Gracia, A. \& Jiménez-Sáez, F. 2008. Benchmarking innovation in the Valencian community. European Urban and Regional Studies 15:4, 333-347. 


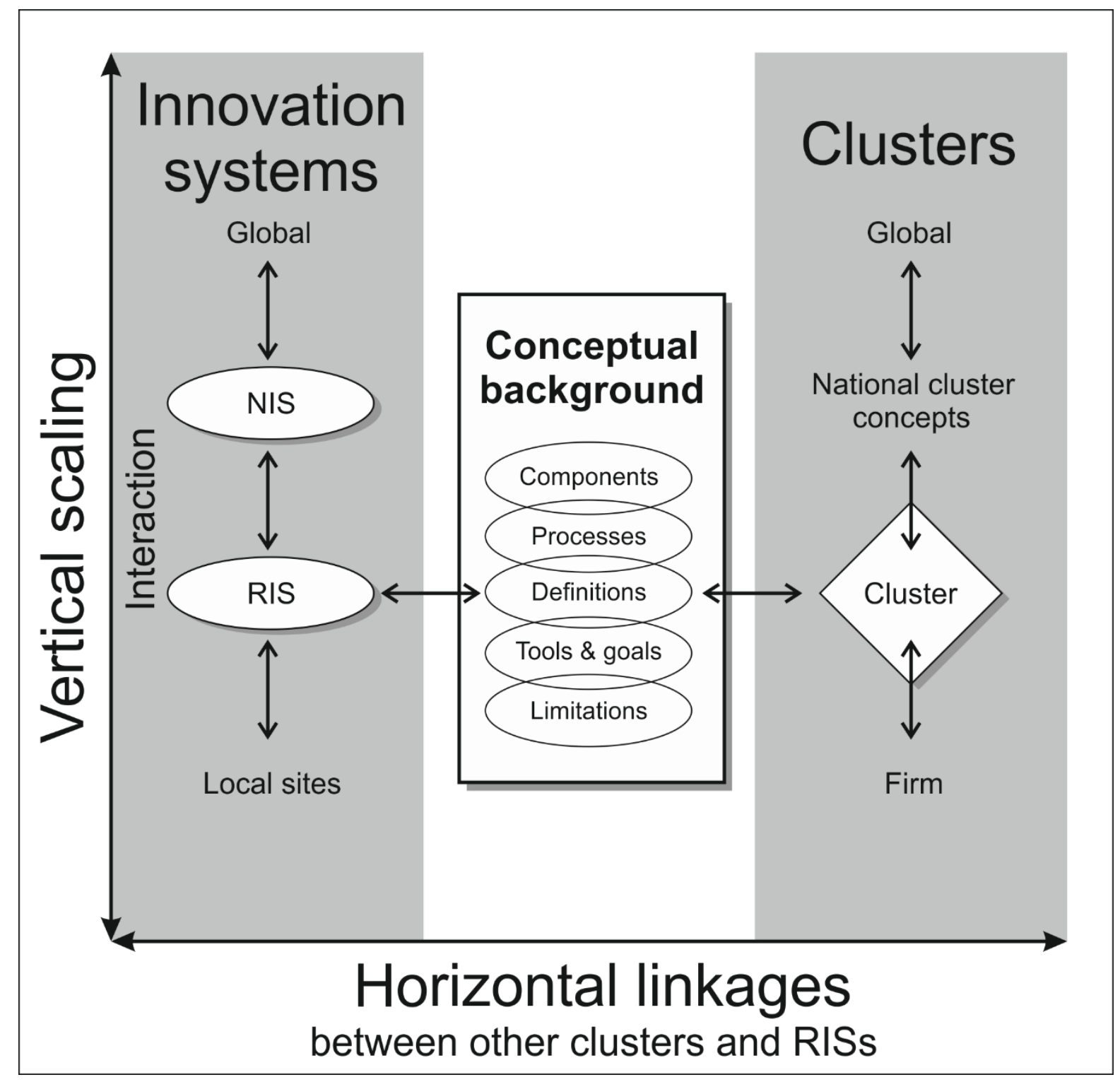

Fig. 1. Conceptual framework of the study 

1. Uusimaa
2. Southwest Finland
3. Häme
4. Päijät-Häme
5. Kymenlaakso
6. South Karelia
7. Satakunta
8. Pirkanmaa (Tampere Region)
9. Central Finland
10. Etelä-Savo
11. Ostrobothnia
12. South Ostrobothnia
13. Central Ostrobothnia
14. Pohjois-Savo
15. North Karelia
16. Northern Ostrobothnia (Oulu Region)
17. Kainuu
(2005-2012: Joint Authority of Kainuu Region) 18. Lapland

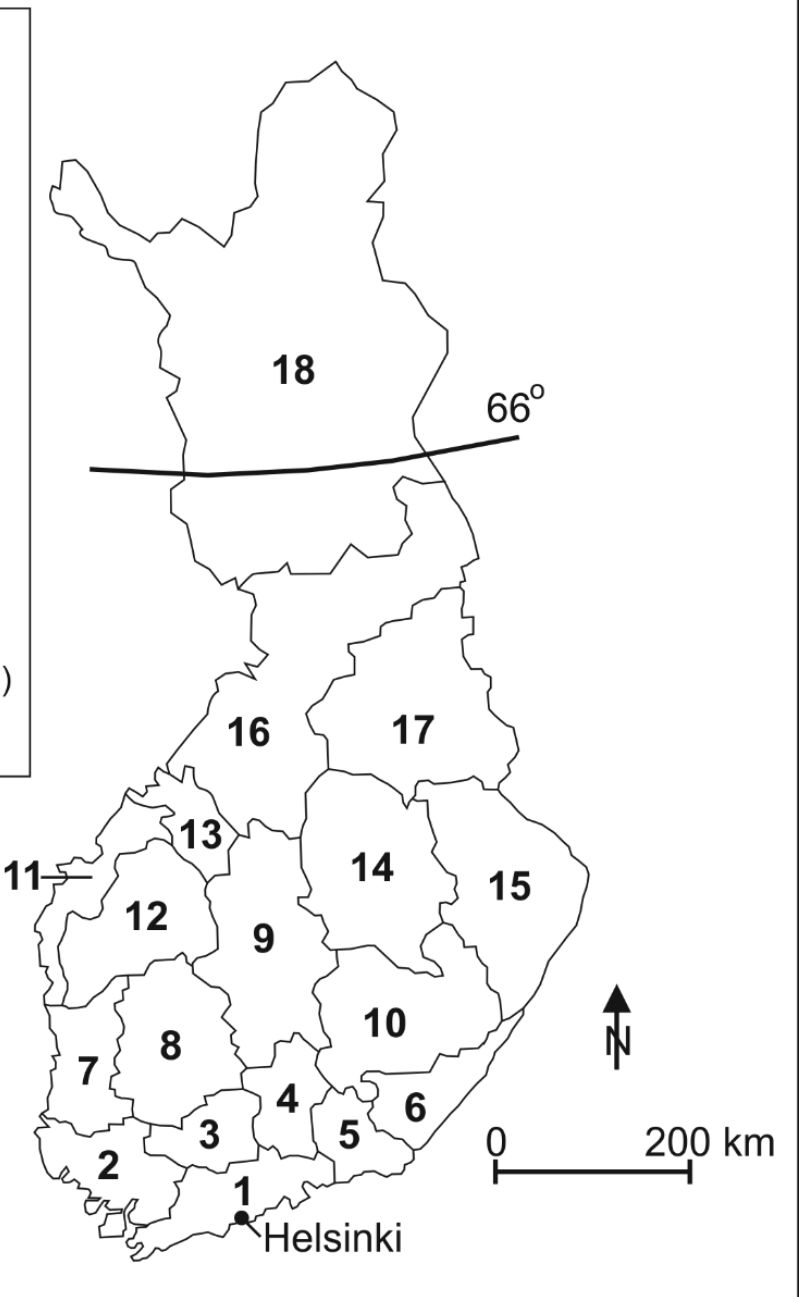

Fig. 2. Finnish regional councils 


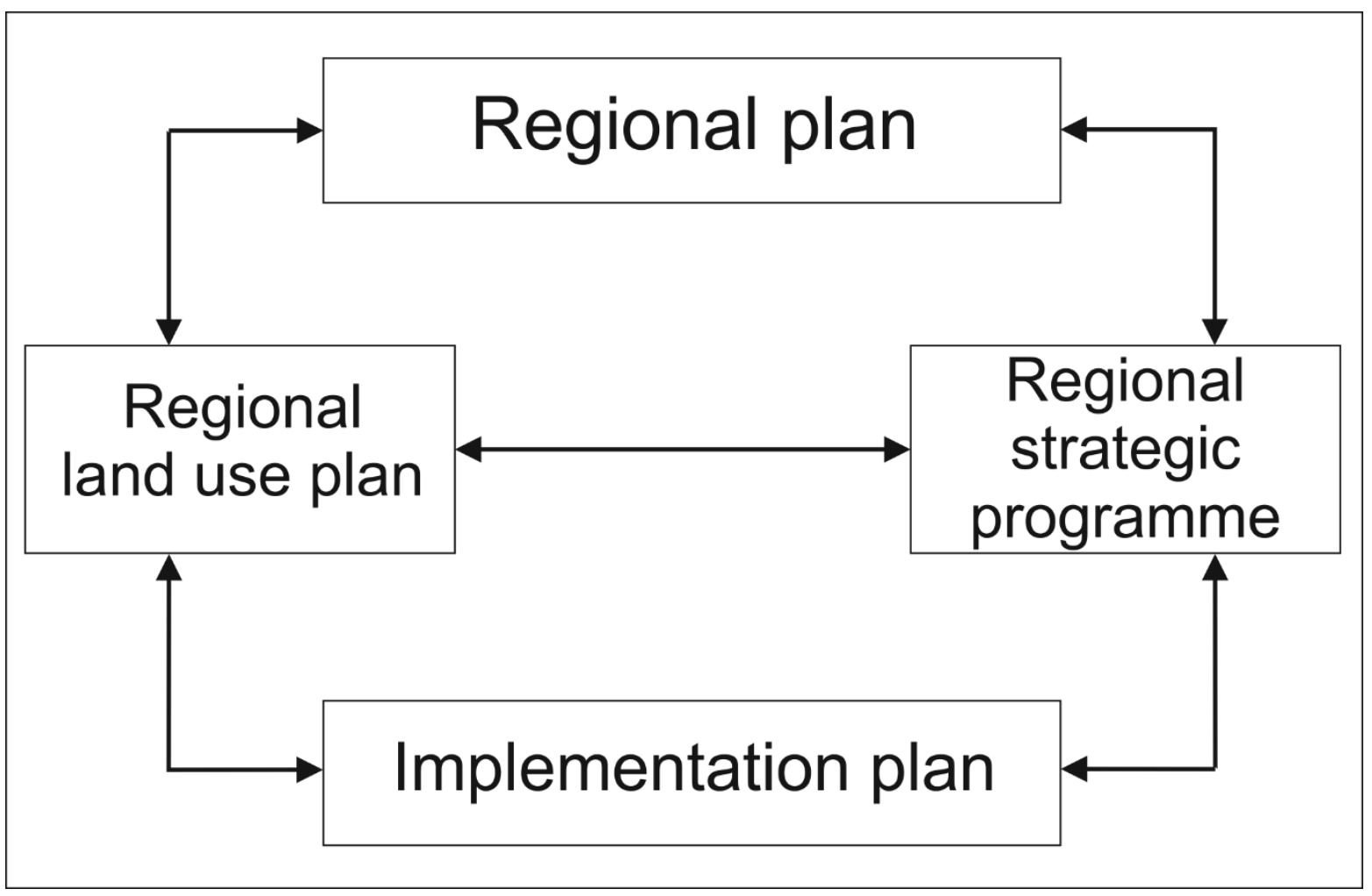

Fig. 3. Strategic regional planning in Finland

Table 1. Population characteristics of Finnish NUTS-3 regions in 2008 (Source: Statistics Finland 2012a; 2012b; 2012c).

\begin{tabular}{lllll} 
& Population & Higher education & Age over 65 years & Unemployment \\
\hline Uusimaa & 1501,511 & $10.3 \%$ & $13.1 \%$ & $4.8 \%$ \\
Southwest Finland & 461,177 & $6.3 \%$ & $17.7 \%$ & $5.7 \%$ \\
Häme & 173,041 & $4.4 \%$ & $18.3 \%$ & $5.8 \%$ \\
Päijät-Häme & 200,847 & $3.9 \%$ & $18.6 \%$ & $6.2 \%$ \\
Kymenlaakso & 182,754 & $3.5 \%$ & $20.1 \%$ & $7.7 \%$ \\
South Karelia & 134,448 & $4.3 \%$ & $20.6 \%$ & $6.6 \%$ \\
Satakunta & 227,652 & $3.5 \%$ & $20.2 \%$ & $6.0 \%$ \\
Pirkanmaa & 480,705 & $6.8 \%$ & $16.8 \%$ & $7.0 \%$ \\
Central Finland & 271,747 & $5.7 \%$ & $17.5 \%$ & $8.1 \%$ \\
Etelä-Savo & 156,632 & $3.6 \%$ & $22.3 \%$ & $7.9 \%$ \\
Ostrobothnia & 175,985 & $5.2 \%$ & $18.5 \%$ & $4.7 \%$ \\
South Ostrobothnia & 193,511 & $3.1 \%$ & $19.1 \%$ & $5.4 \%$ \\
Central Ostrobothnia & 67,991 & $3.5 \%$ & $17.1 \%$ & $6.0 \%$ \\
Pohjois-Savo & 248,423 & $4.7 \%$ & $18.9 \%$ & $7.8 \%$ \\
North Karelia & 166,129 & $4.5 \%$ & $19.1 \%$ & $10.7 \%$ \\
Northern Ostrobothnia & 389,182 & $5.7 \%$ & $14.2 \%$ & $8.3 \%$ \\
Kainuu & 83,160 & $3.5 \%$ & $20.4 \%$ & $11.2 \%$ \\
Lapland & 183,963 & $3.8 \%$ & $18.3 \%$ & $9.9 \%$
\end{tabular}


Table 2. Summary of the features of regional innovation systems (RISs) and clusters in the regional strategic programmes listed in Appendix 1 (number of paragraphs by theme and category).

\section{THEMES}

\begin{tabular}{lll} 
CATEGORIES & Regional innovation systems & Clusters \\
\hline Components & $14(12 \%)$ & $54(28 \%)$ \\
Processes & $14(12 \%)$ & $9(4 \%)$ \\
Definition & $5(4 \%)$ & $1(1 \%)$ \\
Limitations & $4(4 \%)$ & $2(1 \%)$ \\
Development tools and goals & $77(68 \%)$ & $128(66 \%)$ \\
Total & $114(100 \%)$ & $194(100 \%)$
\end{tabular}

Table 3. Summary of the features of regional innovation systems (RISs) and clusters in the regional strategic programmes.

\begin{tabular}{|c|c|c|}
\hline \multirow[b]{2}{*}{ Components } & RISs & Clusters \\
\hline & firms, intermediaries and institutes & firms, government and institutes \\
\hline Processes & $\begin{array}{l}\text { cooperation, networks and } \\
\text { technology transfer }\end{array}$ & $\begin{array}{l}\text { interfaces, cooperation and } \\
\text { networks }\end{array}$ \\
\hline \multirow[t]{2}{*}{ Definition } & $\begin{array}{l}\text { a construct of the interaction } \\
\text { between institutes, intermediaries } \\
\text { and firms' }{ }^{1}\end{array}$ & $\begin{array}{l}\text { a know-how agglomeration } \\
\text { comprised of functionally } \\
\text { interlinked enterprises, institutes } \\
\text { and the government }{ }^{2}\end{array}$ \\
\hline & imprecise theoretical delineation & fuzzy sectoral boundaries \\
\hline \multirow[t]{2}{*}{ Limitations } & implementation & implementation \\
\hline & (lack of) critical considerations & realization of geographical scales \\
\hline $\begin{array}{l}\text { Development tools } \\
\text { and goals }\end{array}$ & $\begin{array}{l}\text { attractiveness, know-how, regional } \\
\text { competitiveness and university- } \\
\text { industry partnerships }\end{array}$ & $\begin{array}{l}\text { employment, know-how, } \\
\text { operational preconditions and } \\
\text { regional competitiveness }\end{array}$ \\
\hline \multicolumn{3}{|c|}{${ }^{1}$ Keski-Pohjanmaan Liitto $(2010,17)$} \\
\hline
\end{tabular}




\section{Appendix 1}

Regional strategic programmes analysed (in Finnish).

1. Uusimaa. Uudenmaan maakuntaohjelma 2011-2014. 37pp. Uudenmaan liitto, Helsinki.

2. Southwest Finland. Kompassi tulevaisuuteen: Varsinais-Suomen maakuntaohjelma 2011-2014. 41pp. Varsinais-Suomen liitto, Turku.

3. Häme. Hämeen maakuntaohjelma 2011-2014. 30pp. Hämeen liitto, Hämeenlinna.

4. Päijät-Häme. Päijät-Häme 2011-2014: Maakuntaohjelma. 31pp. Päijät-Hämeen liitto, Lahti.

5. Kymenlaakso. Nupit kaakkoon - Kohti uutta elinkeinorakennetta: Kymenlaakson maakuntaohjelma $2011-$ 2014. 40pp. Kymenlaakson liitto, Kotka.

6. South Karelia. Etelä-Karjalan maakuntaohjelma 2011-2014. 49pp. Etelä-Karjalan liitto, Lappeenranta.

7. Satakunta. Satakunnan maakuntaohjelma: 2011-2014: Osaava Satakunta, saavutettava Satakunta, energinen ja hyvinvoiva Satakunta. 21pp. Satakuntaliitto, Pori.

8. Pirkanmaa (Tampere Region). Pirkanmaan maakuntaohjelma 2011-2014. 22pp. Pikanmaan liitto, Tampere.

9. Central Finland. Keski-Suomen maakuntaohjelma 2010-2014: Keski-Suomen kasvuohjelma. 31pp. KeskiSuomen liitto, Jyväskylä.

10. Etelä-Savo. Etelä-Savon maakuntaohjelma 2011-2014. 54pp. Etelä-Savon maakuntaliitto, Mikkeli.

11. Ostrobothnia. Pohjanmaan maakuntaohjelma 2011-2014: Energiaa huippuosaamisesta, monikulttuurisuudesta ja vahvasta yhteisöllisyydestä. 60pp. Pohjanmaan liitto, Vaasa.

12. South Ostrobothnia. Etelä-Pohjanmaan maakuntaohjelma 2011-2014. 47pp. Etelä-Pohjanmaan liitto, Seinäjoki.

13. Central Ostrobothnia. Elinvoimainen kestävän kasvun maakunta: Keski-Pohjanmaan maakunta-ohjelma 2011-2014. 34pp. Keski-Pohjanmaan liitto, Kokkola.

14. Pohjois-Savo. Pohjois-Savon maakuntaohjelma 2011-2014. 25pp. Pohjois-Savon liitto, Kuopio.

15. North Karelia. Pokat 2014: Pohjois-Karjalan maakuntaohjelma 2011-2014. 74pp. Pohjois-Karjalan maakuntaliitto, Joensuu.

16. Northern Ostrobothnia (Oulu Region). Pohjois-Pohjanmaa - Nuorten maakunta: Maakuntaohjelma 20112014. 45pp. Pohjois-Pohjanmaan liitto, Oulu.

17. Kainuu (Joint Authority of Kainuu Region). Kainuun maakuntaohjelma 2009-2014. 81pp. Kainuun maakunta -kuntayhtymä, Kajaani.

18. Lapland. Lappi pohjoisen luova menestyjä: Lapin maakuntaohjelma 2011-2014. 83pp. Lapin liitto, Rovaniemi. 